Acta Universitatis Lodziensis

www.czasopisma.uni.lodz.pl/foe/

6(339) 2018

DOI: http://dx.doi.org/10.18778/0208-6018.339.11

\author{
Mariusz Andrzejewski \\ Uniwersytet Ekonomiczny w Krakowie, Wydział Finansów i Prawa, \\ Katedra Rachunkowości Finansowej, andrzejm@uek.krakow.pl
}

\title{
Patryk Dunal
}

Uniwersytet Ekonomiczny w Krakowie, Wydział Finansów i Prawa,

Katedra Rachunkowości Finansowej, dunalp@uek.krakow.pl

\section{Paweł Ożga}

Grupa Spearhead International, pawel.ozga@gmail.com

\section{Wierny i rzetelny obraz instrumentów pochodnych w sprawozdaniu finansowym według modelu rachunkowości zabezpieczeń w dobie MSSF 9}

\begin{abstract}
Streszczenie: Zasady rachunkowości instrumentów pochodnych zawarte w Międzynarodowym Standardzie Rachunkowości 39 (MSR 39) były przedmiotem krytyki z uwagi na stopień skomplikowania i niedopasowanie do rzeczywistości biznesowej. Zastąpienie MSR 39 Międzynarodowym Standardem Sprawozdawczości Finansowej 9 (MSSF 9) miało z jednej strony uprościć zasady rachunkowości zabezpieczeń i przyczynić się do jej szerszego stosowania, a z drugiej wyeliminować niedoskonałości poprzedniego standardu i poprawić jakość informacji na temat instrumentów pochodnych, przekazywanej w sprawozdaniu finansowym. MSSF 9 wprowadził wiele zmian w zakresie rachunkowości instrumentów pochodnych i dlatego też zasadna wydaje się dyskusja na temat ich konsekwencji i wpływu na rzetelność i wiarygodność informacji przekazywanej otoczeniu. Jest to niezwykle istotne, gdyżz instrumentami pochodnymi wiąże się znaczne ryzyko - ich nieumiejętne stosowanie niejednokrotnie prowadziło do znacznych problemów finansowych lub upadłości przedsiębiorstw i instytucji finansowych. Celem niniejszego artykułu jest przedstawienie najważniejszych zmian w rachunkowości instrumentów pochodnych zaimplementowanych w MSSF 9 oraz analiza ich wpływu na walory informacyjne sprawozdań finansowych jednostek gospodarczych, tj. wierne i rzetelne odzwierciedlenie ekonomicznych efektów stosowania derywatów.
\end{abstract}

Słowa kluczowe: instrumenty pochodne, rachunkowość zabezpieczeń, MSSF 9, MSR 39, efektywność zabezpieczenia

JEL: M41, G39 


\section{Wprowadzenie}

Istnieje powszechne przekonanie, że sprawozdania finansowe jednostek gospodarczych i grup kapitałowych stanowią ustrukturyzowaną reprezentację sytuacji majątkowej, finansowej oraz działań jednostki (grupy), która powinna zostać sporządzona i zaprezentowana w sposób gwarantujących ich użyteczność (Ignatowski, 2017). Jakość informacji zawartej w sprawozdaniach finansowych jest kwestią kluczową w podejmowaniu optymalnych decyzji inwestycyjnych, zwłaszcza uczestników obrotu giełdowego (Andrzejewski, Grabiński, 2016).

Rozwój rynków finansowych, a w konsekwencji wzrost powszechności stosowania instrumentów pochodnych oraz związane z nimi ryzyko finansowe spowodowały konieczność ich odpowiedniej ewidencji i prezentacji w sprawozdaniach finansowych (Mazurowska, 2015). W sferze regulacji swoje zainteresowanie problematyką rachunkowości zabezpieczeń wykazała Międzynarodowa Rada Standardów Rachunkowości (International Accounting Standard Board). Obecnie znajdujemy się w nowej rzeczywistości standaryzacyjnej w zakresie rachunkowości zabezpieczeń. Do tej pory najważniejszym uregulowaniem dotyczącym instrumentów pochodnych był Międzynarodowy Standard Rachunkowości nr 39. Od 1 stycznia 2018 roku wszedł w życie nowy standard - Międzynarodowy Standard Sprawozdawczości Finansowej 9, tzw. MSSF 9. Jego implementacja do regulacji prawa bilansowego powoduje pewne konsekwencje dla wierności i rzetelności obrazu sytuacji majątkowej i finansowej prezentowanej w sprawozdaniach finansowych jednostek gospodarczych w zakresie informacji o instrumentach pochodnych. Zaburzenie rzeczywistego i wiernego obrazu może być powodem błędnych decyzji zarządczych dotyczących wykorzystania instrumentów zabezpieczających (Charnes, Koch, Berkman, 2003). Konsekwencją naruszenia wiarygodnego obrazu jednostki może być również brak zainteresowania ze strony inwestorów charakteryzujących się awersją do ryzyka (Michelson, Jordan-Wagner, Wootton, 2000). Z uwagi na fakt, że system rachunkowości podlega nieustannym zmianom, zasadna wydaje się dyskusja na temat następstw wprowadzania kolejnych uregulowań w tym zakresie.

Celem niniejszego artykułu jest przedstawienie problematyki rachunkowości zabezpieczeń w świetle nowo wprowadzonego standardu MSSF 9. Dokonana zostanie analiza potencjalnych szans i zagrożeń wynikających z zastąpienia MSR 39 rozwiązaniami zawartymi w MSSF 9, mającymi wpływ na jakość informacji prezentowanej w sprawozdaniach finansowych jednostek gospodarczych. W niniejszym opracowaniu jako metodę badawczą wykorzystano studia literaturowe oraz pogłębioną analizę treści dokumentów (MSR 39 i MSSF 9). 


\section{Zasady stosowania modelu rachunkowości zabezpieczeń}

W ramach systemu rachunkowości jako kategoria szczegółowa zawarta w rachunkowości instrumentów pochodnych występuje rachunkowość zabezpieczeń. Polega ona na odpowiedniej, to jest przewidzianej w standardach, ewidencji i prezentacji wykorzystania instrumentów pochodnych w celach zabezpieczających (Kamela-Sowińska, Garstecki, 2014). W prawie bilansowym istnieją dwa modele rachunkowości instrumentów pochodnych:

1) model ogólny, polegający na prezentacji takich instrumentów w aktywach lub zobowiązaniach finansowych wycenianych w wartości godziwej przez wynik finansowy,

2) rachunkowość zabezpieczeń, która pozwala na odmienną prezentację takich instrumentów w sprawozdaniu finansowym przy zachowaniu symetrycznego ujęcia zmian wartości pozycji zabezpieczanej i instrumentu zabezpieczającego.

Instrumentem zabezpieczającym może być instrument pochodny bądź inny składnik aktywów lub zobowiązań finansowych (dotyczy to jedynie zabezpieczenia ryzyka walutowego), co do którego oczekuje się, że jego wartość godziwa lub wynikające z niego przepływy pieniężne będą kompensowały zmiany wartości godziwej lub przepływów pieniężnych pozycji podlegającej zabezpieczeniu (Ring, 1997). W myśl prawa bilansowego instrumenty, które zostały zastosowane w celach zabezpieczających, jednostka jest zobowiązana klasyfikować w aktywach lub zobowiązaniach finansowych wycenianych w wartości godziwej przez wynik finansowy. Powoduje to konieczność ich wyceny na każdy dzień bilansowy do wartości godziwej, a efekty zmian tej wyceny są odnoszone do rachunku zysków i strat (Frendzel, 2010). Z kolei wobec instrumentów pochodnych, które służą celom zabezpieczającym, jednostka może (ale nie musi), po spełnieniu wymogów określonych w standardach (MSR 39 i MSSF 9), stosować odmienne zasady rachunkowości, czyli tak zwaną rachunkowość zabezpieczeń.

Rachunkowość zabezpieczeń jest zatem pewnego rodzaju wyjątkiem w standardowym systemie rachunkowości. Jej stosowanie jest przywilejem, a nie bezwarunkowym obowiązkiem. W przypadku gdy jednostka chce stosować ten model rachunkowości instrumentów pochodnych, jest zobowiązana spełnić określone prawem warunki (Żebruń, 2010).

W polskim prawie bilansowym ogólne warunki stosowania rachunkowości zabezpieczeń wynikają z Ustawy z dnia 29 września 1994 r. o rachunkowości (Dz.U. z 2018 r., poz. 395 - art. 35a ust. 3), w której dokonano określenia instrumentów finansowych służących zabezpieczeniu. W myśl jej przepisów instrumenty „uznaje 
się za służące ograniczeniu ryzyka związanego z aktywami lub pasywami jednostki, tj. zabezpieczeniu tych aktywów lub pasywów, jeżeli co najmniej:

1) przed zawarciem kontraktu ustalono jego cel oraz określono, które aktywa lub pasywa mają zostać za pomocą tego kontraktu zabezpieczone,

2) zabezpieczający instrument finansowy będący przedmiotem kontraktu i zabezpieczane za jego pomocą aktywa lub pasywa charakteryzują się podobnymi cechami, a w szczególności wartością nominalną, datą zapadalności, wpływem zmian stopy procentowej lub kursu waluty,

3) stopień pewności oczekiwań dotyczących przewidywanych w wyniku kontraktu przepływów środków pieniężnych jest znaczny".

Warto zauważyć, że stosowanie modelu rachunkowości zabezpieczeń zależy od swobodnego i samodzielnego wyboru jednostki, co należy interpretować jako swoisty wyjątek w porównaniu do standardowych zasad rachunkowości właściwych dla instrumentów finansowych (Helin, Drabikowska, Sztuczyńska, 2005). Należy także wspomnieć, że rachunkowość zabezpieczeń może być stosowana do umów wybranych samodzielnie przez jednostkę. W konsekwencji dopuszczalne jest zatem stosowanie w sposób jednoczesny rachunkowości zabezpieczeń do określonej grupy instrumentów pochodnych, a modelu ogólnego względem pozostałych.

W ogólnym ujęciu celem stosowania modelu rachunkowości zabezpieczeń jest wierne i rzetelne odzwierciedlenie w księgach rachunkowych i sprawozdaniu finansowym ekonomicznego sensu działań zabezpieczających. W efekcie w sposób oczywisty należy wykluczyć z tego modelu instrumenty pochodne wykorzystywane w celach spekulacyjnych.

\section{Zmiany w rachunkowości instrumentów pochodnych wprowadzone przez MSSF 9}

W przyjętym do stosowania od 1 stycznia 2018 roku MSSF 9 nie wprowadzono zmiany zasad modelu ogólnego rachunkowości instrumentów pochodnych. Natomiast $\mathrm{w}$ istotny sposób zmodyfikowano niektóre $\mathrm{z}$ elementów modelu rachunkowości zabezpieczeń. Stosowanie rachunkowości zabezpieczeń jest w dalszym ciągu rozwiązaniem fakultatywnym oraz może odbywać się w sposób wybiórczy, to znaczy w odniesieniu do instrumentów pochodnych swobodnie wskazanych przez jednostkę. Należy również wspomnieć, że wymagania formalne w zakresie stosownego udokumentowania celu oraz strategii zarządzania ryzykiem pozostały w niezmienionej postaci względem MSR 39.

W MSSF 9 wprowadzono pewne zmiany w zakresie desygnowania instrumentów do powiązań zabezpieczających. Dokonano rozszerzenia zakresu instru- 
mentów możliwych do zastosowania w celach zabezpieczających o wszelkie niepochodne aktywa i zobowiązania finansowe wyceniane w wartości godziwej przez wynik finansowy, z wyłączeniem (MSSF 9, par. 6.2.2):

1) zobowiązań finansowych wycenianych w wartości godziwej przez wynik finansowy, dla których zmiana wartości wynikła z ryzyka kredytowego jest ujmowana w innych całkowitych dochodach,

2) komponentu walutowego aktywów lub zobowiązań finansowych, które stanowią inwestycję w instrument kapitałowy i są wyceniane przez inne całkowite dochody.

W rachunkowości instrumentów pochodnych według MSR 39 generalnie nie istniało przyzwolenie na wyznaczenie instrumentu pochodnego jako składnika podlegającego zabezpieczeniu. Jako sytuację wyjątkową dopuszczano jedynie możliwość wyznaczenia opcji nabytej jako pozycji zabezpieczanej lub umowy z wbudowaną opcją nabytą. W nowo wprowadzonym standardzie MSSF 9 pojawiły się istotne zmiany w tym zakresie. Dozwolone jest desygnowanie do zabezpieczenia zagregowanej pozycji, stanowiącej połączenie składnika sprawozdania z sytuacji finansowej lub planowanej transakcji z dowolnym instrumentem pochodnym, który rozpatruje się w sposób łączny wraz z pozycją jako jeden element generujący ekspozycję na ryzyko. Dla przykładu spółka może zabezpieczyć ryzyko cen oleju napędowego, zawierając towarowy i walutowy instrument pochodny. Do powiązania zabezpieczającego ryzyko walutowe jako pozycję zabezpieczaną jednostka może, zgodnie z paragrafem 6.3.4 MSSF 9, wyznaczyć planowaną transakcję zakupu oraz towarowy instrument pochodny. Do tej pory - w czasach obowiązywania MSR 39 - pozycją zabezpieczaną mogła być jedynie planowana transakcja. Po implementacji MSSF 9 jednostka gospodarcza ma możliwość wyznaczenia jako pozycji zabezpieczanej kombinacji planowanej transakcji z instrumentem pochodnym zabezpieczającym ryzyko towarowe.

Podsumowując powyższe rozważania dotyczące zasad stosowania rachunkowości zabezpieczeń według MSR 39, należy stwierdzić, że tego modelu nie można było wykorzystywać w sytuacji, gdy:

1) instrument zabezpieczający wygasł, został sprzedany, rozwiązany lub wykonany (nie dotyczy sytuacji rolowania instrumentu, jeżeli stanowi to element strategii zarządzania ryzykiem),

2) zabezpieczenie przestało spełniać kryteria rachunkowości zabezpieczeń, w szczególności wymogu wysokiej efektywności,

3) jednostka unieważniła powiązanie zabezpieczające,

4) zaprzestano oczekiwać realizacji planowanej transakcji.

Natomiast po wprowadzeniu MSSF 9 zaprzestanie stosowania rachunkowości zabezpieczeń jest możliwe w sytuacji, gdy istniejące powiązanie przestaje spełniać wymogi tego modelu, po uwzględnieniu możliwych sposobów jego dostosowania, dopuszczanych przez standard. Obejmuje to sytuacje wygaśnięcia, zbycia, rozwią- 
zania lub wykonania instrumentu zabezpieczającego (z wyjątkiem rolowania), jak również zaprzestania oczekiwania realizacji planowanej transakcji będącej przedmiotem zabezpieczenia (MSSF 9, par. 6.5.6).

Należy również zauważyć, że w MSSF 9 nie przewidziano możliwości unieważnienia powiązania zabezpieczającego w sposób prospektywny, co miało miejsce w MSR 39. Zmiana ta powinna być zatem rozpoznana jako pozytywna, ponieważ istnienie możliwości dobrowolnego zaprzestania stosowania rachunkowości zabezpieczeń w pewnych przypadkach może być wykorzystywane do manipulowania wynikiem finansowym, co jest niezgodne z zasadą rzetelnego i wiernego obrazu (true and fair view) - jedną z nadrzędnych zasad rachunkowości (Barczyk, 2015).

Nowym rozwiązaniem wprowadzonym przez MSSF 9 jest także możliwość zaprzestania stosowania rachunkowości zabezpieczeń w odniesieniu do części powiązania lub do jego całości (MSSF 9, par. 6.5.6), podczas gdy MSR 39 odnosi się jedynie do całości powiązania zabezpieczającego. Ponadto MSSF 9 zmienił sposób ujmowania wartości czasowej opcji, jeżeli nie została desygnowana jako instrument zabezpieczający do powiązania. Według MSR 39 zmiany wartości czasowej były ujmowane na bieżąco przez wynik finansowy, co powodowało dodatkową zmienność w rachunku zysków i strat (Comiskey, Mulford, 2008). Według MSSF 9 wartość czasowa opcji niewyznaczona do powiązania będzie ujmowana w kapitale $\mathrm{z}$ aktualizacji wyceny i odpisywana sukcesywnie $\mathrm{w}$ trakcie trwania zabezpieczenia lub w momencie realizacji pozycji zabezpieczanej, w zależności od charakteru ustanowionego zabezpieczenia (MSSF 9, par. 6.5.15). To podejście dotyczy tylko opcji, dla których jednostka stosuje rachunkowość zabezpieczeń. Dla opcji klasyfikowanych jako aktywa lub zobowiązania finansowe wyceniane w wartości godziwej przez wynik finansowy zmiany wartości godziwej ujmowane są identycznie jak dotychczas, to jest w rachunku zysków i strat.

\section{Reforma efektywności zabezpieczenia w MSSF 9}

Przez pojęcie „efektywność zabezpieczenia” w teorii rachunkowości rozumie się względną miarę określającą stopień wzajemnego kompensowania zmian wartości godziwej pozycji zabezpieczanej ze zmianami wartości godziwej instrumentu zabezpieczającego (Ożga, 2016; Ramirez, 2007). Z kolei w naukach ekonometrycznych i teorii rynków finansowych efektywność zabezpieczenia najczęściej definiuje się jako względną miarę redukcji ryzyka portfela zabezpieczonego względem portfela niezabezpieczonego (Bera, Garcia, Roj, 1973; Howard, D’Antonio, 1987). Pożądanym wynikiem efektywności zabezpieczenia jest wykazanie, że instrument pochodny, wykorzystany do zabezpieczenia danej pozycji bilansowej lub planowanej transakcji, rzeczywiście spełnia (lub spełni) swoją rolę. Sprawa ta jest 
kluczowa w kontekście możliwości stosowania modelu rachunkowości zabezpieczeń (Dunal, Kozik, 2017). Wysoką efektywność zabezpieczenia po raz pierwszy zdefiniowano na początku lat dziewięćdziesiątych XX wieku, a później to pojęcie nieco ewoluowało. Pod koniec ostatniej dekady XX wieku przedział 80-125\% stał się powszechnie akceptowanym standardem w praktyce rynkowej w Stanach Zjednoczonych (Finnerty, Grant, 2003) i dzięki temu został zaimplementowany do europejskiego prawa bilansowego (MSR 39).

Poziom efektywności ustanowionego powiązania zabezpieczającego jest kluczowym warunkiem dopuszczającym stosowanie modelu rachunkowości zabezpieczeń (Garstecki, 2012). Według MSR 39 wymagane było testowanie efektywności w dwóch ujęciach: prospektywnym (ex ante) i retrospektywnym (ex post). W obydwu jednostka gospodarcza powinna wykazywać wysoki poziom efektywności, to jest wartość z przedziału $80-125 \%$. W ocenie autorów w tym zakresie dokonano największej rewolucji we wprowadzonym MSSF 9. Przedział ilościowy $80-125 \%$ został usunięty. Stanowi to kluczową zmianę z uwagi na decydującą rangę tego właśnie warunku w zakresie dopuszczalności stosowania rachunkowości zabezpieczeń. Według nowych wytycznych zawartych w paragrafie 6.4.1 MSSF 9 stosowanie tego modelu jest możliwe w przypadku, gdy powiązanie zostało odpowiednio udokumentowane oraz spełnia następujące kryteria efektywności:

1) między instrumentem zabezpieczającym i pozycją zabezpieczaną istnieje zależność ekonomiczna;

2) wpływ ryzyka kredytowego na zmiany wartości godziwej jest istotnie niższy niż wpływ ryzyka poddanego zabezpieczeniu (będącego skutkiem ekonomicznej zależności);

3) współczynnik zabezpieczenia (hedge ratio) jest wynikiem relacji wielkości pozycji zabezpieczanej i instrumentu zabezpieczającego.

W nowo wprowadzonym MSSF 9 nie istnieje zatem konieczność pełnej efektywności ustanowionego powiązania. Decydującym czynnikiem są oczekiwane zmiany wartości godziwej pozycji zabezpieczającego względem pozycji podlegającej zabezpieczeniu, a nie faktyczny stopień kompensaty wartości godziwej pozycji zabezpieczającej i zabezpieczanej. Ewentualne różnice w zmianach wartości godziwej obu tych elementów mogą wystąpić, ale powinny mieć one charakter przypadkowy, to znaczy powinny być niemożliwe do przewidzenia lub oszacowania w momencie przeprowadzania testu.

Inna istotna zmiana w MSSF 9 względem MSR 39 jest związana z rodzajami testów wykorzystywanych do pomiaru efektywności zabezpieczenia. W MSSF 9 wprowadzono wymaganie o przeprowadzaniu badania powiązania na dzień jego ustanowienia, natomiast $\mathrm{w}$ trakcie jego trwania najbardziej istotna jest identyfikacja potencjalnych źródeł nieefektywności, a nie sam pomiar efektywności (jak w MSR 39). Dodatkowo, zgodnie z paragrafem 6.4.1 MSSF 9, celem pomiaru efektywności jest weryfikacja dopasowania zabezpieczenia, a zatem dokonanie te- 
stu sprawdzającego, czy ustanowione powiązanie zminimalizuje zidentyfikowaną nieefektywność. Te wymagania obligują więc jednostkę gospodarczą do testowania efektywności zabezpieczenia jedynie ex ante. Takie rozwiązanie może być zatem interpretowane jako spore uproszczenie w porównaniu do kryteriów MSR 39, z uwagi na zniesienie obowiązku przeprowadzania testu retrospektywnego. Niemniej jednak w praktyce w MSSF 9 podtrzymano samą metodologię szacowania części efektywnej instrumentu zabezpieczającego, która nie może być większa niż bezwzględna zmiana wartości godziwej pozycji zabezpieczanej (MSSF 9, par. 6.5.11). W konsekwencji w dalszym ciągu jednostki gospodarcze będą zobligowane do dokonywania wyceny instrumentu zabezpieczającego na każdy dzień bilansowy oraz rejestrowania zmian wartości pozycji zabezpieczanej w trakcie trwania powiązania. Oba te elementy stanowiły w MSR 39 podstawę do przeprowadzania testów retrospektywnych. Podsumowując, w sposób formalny testowanie retrospektywne nie stanowi wymogu, natomiast znaczna część czynności z tym związanych musi zostać wykonana w celu ustalenia wspomnianej części efektywnej instrumentu zabezpieczającego.

Zmiany wprowadzone w MSSF $9 \mathrm{w}$ zakresie pomiaru efektywności zabezpieczenia mają swoje odzwierciedlenie również w samym sposobie dokonywania oceny efektywności na podstawie wyników testu. Warunek ilościowy obowiązujący w MSR 39 powodował, że same testy efektywności również musiały charakteryzować się cechami ilościowymi. Standard ten nie wskazywał jednak na odpowiednie metody szacowania efektywności. W MSSF 9 również nie została zdefiniowana konkretna metodologia w tym zakresie. Niemniej jednak istnieje wymaganie, aby wykorzystywana metoda obejmowała charakterystykę powiązania zabezpieczającego, w tym w szczególności źródła potencjalnej nieefektywności. Odejście od obowiązującego charakteru ilościowego testów efektywności zabezpieczenia stworzyło możliwość pojawienia się jakościowych metod oceny. Zmiana ta jest zatem bardzo istotna i może stanowić bodziec do ukształtowania się nowych sposobów oceny skuteczności powiązań zabezpieczających, a w szczególności nowych, subiektywnych kryteriów definiowania wysokiej efektywności. Kolejną znaczącą zmianą wprowadzoną przez MSSF 9 jest możliwość wybrania innej metody pomiaru efektywności w trakcie trwania powiązania zabezpieczającego, co nie jest dozwolone w MSR 39. Warto jednak zauważyć, że taka możliwość będzie dopuszczalna w momencie zaistnienia okoliczności, które mają wpływ na otrzymywane wyniki testów efektywności. W konsekwencji jeżeli na podstawie przyjętej do zastosowania metody powiązanie okaże się nieskuteczne, jednostka gospodarcza będzie mogła dokonać zmiany tej metody na inną, która w jej ocenie pozwoli udowodnić wysoką efektywność. Tę zmianę należy ocenić jednak w sposób negatywny, ponieważ wzrasta ryzyko manipulowania obrazem sytuacji jednostki gospodarczej w zakresie wykorzystywania instrumentów pochodnych. 


\section{Ocena zmian MSSF 9 w kontekście zasady true and fair view}

Rozwiązania zawarte w MSR 39 były przedmiotem krytyki nie tylko ze względu na stopień ich skomplikowania (Corman, 2006), ale także z uwagi na możliwe wypaczenia i zniekształcenia informacji przekazywanej użytkownikom sprawozdań finansowych (Bernhardt, Erlinger, Unterrainer, 2014). Wskazane najważniejsze zmiany w rachunkowości instrumentów pochodnych wprowadzone przez MSSF 9 są ukierunkowane głównie na uproszczenie modelu rachunkowości zabezpieczeń i rozszerzenie zakresu jego stosowania. Ich wpływ na wierny i rzetelny obraz instrumentów pochodnych prezentowany w sprawozdaniu finansowym nie jest jednak jednoznaczny.

Ograniczenie pomiaru efektywności jedynie do wariantu prospektywnego i usunięcie miary ilościowej wysokiej efektywności niewątpliwie mają na celu zmniejszenie pracochłonności związanej ze stosowaniem tego modelu oraz zwiększenie zakresu instrumentów i strategii, które mogą być ujmowane według zasad rachunkowości zabezpieczeń (np. wyceniane przez kapitał z aktualizacji wyceny, a nie przez wynik finansowy). Idea uproszczeń wydaje się słuszna, jednak należy zauważyć, że pewne rozwiązania MSSF 9 mogą rodzić wątpliwości. Przykładowo, brak jasno określonego kryterium uznania powiązania zabezpieczającego za efektywne wprowadza dużą dowolność interpretacji, co może przekładać się na gorszą porównywalność sprawozdań finansowych. Różne jednostki mogą inaczej rozumieć wysoką efektywność i w konsekwencji ujmować w modelu rachunkowości zabezpieczeń instrumenty, które w rzeczywistości w niezbyt wysokim stopniu kompensują zmiany wartości pozycji zabezpieczanej.

Kolejną dyskusyjną kwestią jest możliwość zmiany metody pomiaru efektywności w trakcie trwania powiązania. MSR 39 wymagał stosowania jednej metody w sposób ciągły, podczas gdy MSSF 9 dopuszcza jej zmianę w sytuacji, kiedy dotychczas stosowana wskazuje na nieefektywność (MSSF 9, par. B6.4.17). W tym miejscu należy wspomnieć jedną z nadrzędnych zasad rachunkowości - zasadę ciągłości. Można mieć zastrzeżenia, czy możliwość zmiany metody pomiaru efektywności zabezpieczenia nie stanowi jej naruszenia. Niewątpliwie powoduje ona obniżenie porównywalności informacji i może być wykorzystana do manipulowania wynikiem finansowym, w szczególności przez zmianę metody można utrzymać nieefektywne instrumenty w rachunkowości zabezpieczeń, zwłaszcza w sytuacji, w której standard nie precyzuje dopuszczalnych metod pomiaru efektywności.

Należy zaznaczyć, że MSSF 9 zawiera także zmiany poprawiające użyteczność i jakość przekazywanej otoczeniu informacji na temat stosowanych instrumentów pochodnych. Zgodnie z założeniami koncepcyjnymi sporządzania 
i prezentacji sprawozdań finansowych (Conceptual Framework, par. 2.4) fundamentalne znaczenie dla użyteczności informacji ma przydatność, to jest wpływ na decyzje podejmowane przez jej posiadaczy oraz wierne odzwierciedlenie rzeczywistości. Rozszerzenie katalogu instrumentów oraz pozycji kwalifikujących się do zabezpieczenia pozwoli jednostkom lepiej odzwierciedlić rzeczywistość ekonomiczną. Bardzo często bowiem jednostki gospodarcze stosują tak zwany hedging naturalny (tj. bez wykorzystania instrumentów pochodnych) lub zabezpieczają pozycję zagregowaną, w skład której wchodzi inny instrument pochodny. MSR 39 nie pozwalał w takich sytuacjach stosować rachunkowości zabezpieczeń, przez co ekonomiczne skutki zabezpieczenia nie były prawidłowo prezentowane. MSSF 9 obejmuje swoim zakresem wspomniane sytuacje, dzięki czemu przyczynia się do realizacji zasady wiernego i rzetelnego obrazu.

Kolejną istotną zmianą w MSSF 9 jest tak zwany rebalancing, czyli możliwość dostosowania powiązania zabezpieczającego w trakcie jego trwania (Fabozzi, Markowitz, 2011). MSR 39 nie dopuszczał takiej możliwości, przez co wiele strategii nie kwalifikowało się do rachunkowości zabezpieczeń. Rzeczywistość gospodarcza jest zmienna i często wymaga działań dostosowawczych. W przypadku hedgingu można mówić o zmianach dotyczących pozycji zabezpieczanej, rodzajów ryzyka czy daty realizacji. Jednostki często stosują hedging dynamiczny, który w MSR 39 musiał być z reguły ujmowany według zasad ogólnych, to znaczy przez wynik finansowy, co powodowało dodatkowe wahania w rachunku zysków i strat. MSSF 9 przez rebalancing pozwala na dostosowanie powiązania zabezpieczającego bez konieczności jego zamykania lub unieważniania, przez co umożliwia wierne odzwierciedlenie skutków hedgingu w momencie realizacji pozycji podlegającej zabezpieczeniu (Rashty, O’Shaughnessy, 2012). W omówionych aspektach MSSF 9 znacząco poprawił wierną prezentację działań zabezpieczających, przez co zwiększył użyteczność informacji przekazywanej w sprawozdaniach finansowych.

Pozytywnie należy także ocenić usunięcie możliwości dobrowolnego zaprzestania stosowania zasad rachunkowości zabezpieczeń. MSR 39 dawał podmiotom gospodarczym de facto narzędzie do kreowania wyników finansowych, gdyż jednostka mogła w każdej chwili unieważnić powiązanie zabezpieczające, czyli zmienić sposób ujmowania skutków wyceny derywatów tylko i wyłącznie na podstawie własnej decyzji, bez konieczności motywowania jej zmianami w zakresie zabezpieczanej pozycji lub ryzyka. Miało to szczególne znaczenie w przypadku zabezpieczenia przepływów pieniężnych, gdzie zaprzestanie stosowania mogło poprawić w pewnym stopniu wynik finansowy dzięki odniesieniu zmian wartości godziwej instrumentu zabezpieczającego od ostatniego dnia, w którym udokumentowano wysoką efektywność, nie na kapitał, ale na wynik finansowy.

Analizując najważniejsze zmiany wprowadzone przez MSSF $9 \mathrm{w}$ zakresie rachunkowości instrumentów pochodnych, nie można jednoznacznie stwierdzić, czy przyczynią się one do poprawy jakości informacji na temat tych instrumentów. 
Nowy standard wprowadził zmiany potrzebne, lepiej odzwierciedlające pewne aspekty działań zabezpieczających (np. hedging naturalny, rebalancing), ale jednocześnie w innych obszarach spowodował obniżenie porównywalności, a nawet powstanie ryzyka manipulacji, co stanowi realne zagrożenie dla prezentacji wiernego i rzetelnego obrazu instrumentów pochodnych.

\section{Wady MSR 39 rzutujące na wierny i rzetelny obraz sytuacji finansowej jednostki gospodarczej, kontynuowane w MSSF 9}

W tym miejscu należy wspomnieć o wadach MSR 39, które, niestety, zostały powielone w MSSF 9. Dla realizacji zasady true and fair view niewątpliwie najważniejsze jest odzwierciedlenie w sprawozdaniu finansowym rzeczywistego, ekonomicznego efektu działań zabezpieczających i spekulacyjnych z wykorzystaniem instrumentów pochodnych. O ile w przypadku spekulacji model ogólny spełnia swoją rolę, to znaczy powoduje ujmowanie na bieżąco zysków i strat osiąganych na derywatach, to w przypadku hedgingu nie jest to regułą. Zarówno w MSR 39, jak i MSSF 9 instrumenty zawarte w celach zabezpieczających mogą być ujmowane zarówno według zasad ogólnych, jak i w modelu rachunkowości zabezpieczeń. Oznacza to, że instrumenty zabezpieczające mogą być prezentowane w sprawozdaniu finansowym w taki sam sposób jak instrumenty spekulacyjne. Jest to konsekwencją dobrowolności stosowania rachunkowości zabezpieczeń. Wybiórcze stosowanie tego modelu może prowadzić zatem do zarządzania zyskami (Ryan i in., 2002). W rezultacie odbiorcy sprawozdań finansowych mogą zostać wprowadzeni w błąd, a więc nie można mówić o przekazywaniu im wiernego i rzetelnego obrazu na temat stosowanych instrumentów pochodnych.

Mając na uwadze zasadę true and fair view, należałoby postulować zniesienie dobrowolności rachunkowości zabezpieczeń i powiązanie dostępnych modeli z celami stosowania derywatów, czyli dla instrumentów służących spekulacji czy arbitrażowi - ujmowanie według zasad ogólnych (tj. przez wynik finansowy), a dla instrumentów zabezpieczających - według zasad rachunkowości zabezpieczeń (przez kapitał z aktualizacji wyceny, rozpoznawanie zysków i strat dotyczących instrumentu zabezpieczającego w tym samym okresie co pozycji zabezpieczanej itp.). Takie rozwiązanie pozwoliłoby na odzwierciedlenie w sprawozdaniu finansowym ekonomicznej istoty operacji z udziałem instrumentów pochodnych. W przypadku transakcji spekulacyjnych, to jest nastawionych na osiąganie zysków na skutek wahań na rynkach finansowych, model ogólny (wycena w wartości godziwej przez wynik finansowy) wydaje się najlepszym rozwiązaniem, gdyż pozwala na bieżąco informować otoczenie o zyskach lub stratach osiąganych 
na skutek stosowania derywatów. Z kolei w przypadku hedgingu rachunkowość zabezpieczeń, dzięki odnoszeniu skutków wyceny na kapitał, pozwala zminimalizować wahania wyniku finansowego i rozpoznać wynik osiągnięty na instrumencie zabezpieczającym w tym samym momencie, w którym pozycja podlegająca zabezpieczeniu powoduje powstanie kosztów lub przychodów. W konsekwencji jej wpływ na wynik finansowy jest ujmowany w kwocie faktycznie zabezpieczonej za pomocą instrumentu pochodnego. Wprowadzenie obowiązku stosowania rachunkowości zabezpieczeń pełniłoby też funkcję atestacyjną, to znaczy dawałoby użytkownikom sprawozdań finansowych pewność, że spółka stosuje instrumenty pochodne w celach zabezpieczających, a nie spekulacyjnych. Oczywiście ryzyko celowego zastosowania niewłaściwego modelu, aby manipulować wynikiem finansowym, będzie zawsze istniało. Rolą biegłego rewidenta jest niedopuszczenie do takich sytuacji. W chwili obecnej dobrowolność stosowania rachunkowości zabezpieczeń powoduje, że instrumenty zabezpieczające mogą być ujmowane i prezentowane w taki sam sposób jak spekulacyjne, co może wprowadzać inwestorów w błąd. Wydaje się, że MSSF 9 nie rozwiązał tego kluczowego problemu dla wiernego i rzetelnego obrazu.

Kolejnym elementem, który nie został zmieniony, a ma wpływ na wartość informacyjną sprawozdania finansowego, jest sposób prezentacji zabezpieczanych składników aktywów i zobowiązań w sprawozdaniu z sytuacji finansowej. W chwili obecnej obydwa modele rachunkowości instrumentów pochodnych nie pozwalają na wykazywanie w sprawozdaniu z sytuacji finansowej konkretnych pozycji zabezpieczanych w wartości wynikającej z ustanowionego zabezpieczenia (np. wartości zapasów). W okresie trwania powiązania wartość bilansowa zabezpieczanego składnika aktywów lub pasywów jest korygowana o zmiany wartości godziwej spowodowane przez materializację ryzyka poddanego zabezpieczeniu. Natomiast wartość godziwa instrumentu zabezpieczającego jest prezentowana oddzielnie jako aktywa lub zobowiązania finansowe. Ujęcie w sprawozdaniu z sytuacji finansowej pozycji zabezpieczanej w wartości rzeczywiście zabezpieczonej wymaga korekty jej wartości o wycenę instrumentu zabezpieczającego. Innymi słowy, składniki powiązania powinny zostać skompensowane i wykazane w sprawozdaniu z sytuacji finansowej w kwocie netto (DeMarzo, Duffie, 1995). Tylko wówczas sprawozdanie finansowe odzwierciedlałoby w pełni ekonomiczny efekt hedgingu. Jednak takie rozwiązanie byłoby sprzeczne z zasadą zakazu kompensat. Wydaje się, że właśnie dlatego MSSF 9 utrzymał zakaz kompensowania w sprawozdaniu z sytuacji finansowej wartości instrumentu zabezpieczającego i pozycji zabezpieczanej. W konsekwencji pozycja zabezpieczana nie jest wykazywana w wartości rzeczywiście zabezpieczonej. Wydaje się jednak, że - mimo zasady zakazu kompensat - funkcjonujący model zabezpieczenia wartości godziwej mógłby zostać ulepszony. W celu poprawy jakości informacji przekazywanej do otoczenia $\mathrm{w}$ formie sprawozdania finansowego rachunkowość zabezpieczeń wartości 
godziwej mogłaby nakazywać prezentowanie wyceny instrumentu zabezpieczającego w osobnej linii tej samej pozycji, w której ujmowana jest wartość pozycji zabezpieczanej. Jednak i to zagadnienie nie zostało w MSSF 9 w żaden sposób poruszone.

\section{Pierwsze szacunki wpływu MSSF 9 na sprawozdania finansowe spółek notowanych na GPW w Warszawie}

MSSF 9 został przyjęty do stosowania 1 stycznia 2018 roku. W sprawozdaniach finansowych spółek notowanych na GPW w Warszawie za 2017 rok można znaleźć szacunki wpływu nowego standardu na wartość aktywów i pasywów oraz wynik finansowy i inne całkowite dochody. Tabela 1 prezentuje zestawienie wpływu MSSF 9 na zyski zatrzymane i inne całkowite dochody wybranych spółek.

Tabela 1. Wpływ MSSF 9 na sprawozdania finansowe wybranych spółek (w mln zł)

\begin{tabular}{|l|l|c|c|}
\hline Spółka & \multicolumn{1}{|c|}{ Zmiana } & $\begin{array}{c}\text { Zyski } \\
\text { zatrzymane }\end{array}$ & $\begin{array}{c}\text { Inne całkowite } \\
\text { dochody }\end{array}$ \\
\hline PKO BP & Zmiana klasyfikacji i wyceny & 155 & $(164)$ \\
\hline & Utrata wartości & $(644)$ & \\
\hline ING & Zmiana klasyfikacji i wyceny & $(22)$ & $(40)$ \\
\hline & Korekta odpisów aktualizujących & $(236)$ & 1 \\
\hline KGHM & Zmiana klasyfikacji i wyceny & 707 & $(654)$ \\
\hline & Korekta odpisów aktualizujących & $(16)$ & \\
\hline & Przeklasyfikowanie zmian wartości czasowej opcji & 223 & $(223)$ \\
\hline PZU & Zmiana klasyfikacji i wyceny & 90 & $(146)$ \\
\hline
\end{tabular}

Źródło: sprawozdania finansowe PKO BP, ING, KGHM i PZU za 2017 rok

Pierwsze szacunki pokazują, że zmiany spowodowane wdrożeniem MSSF 9 mogą być znaczące. Spółki, które przeprowadziły taką analizę, wykazują głównie różnice wynikające ze zmiany zasad klasyfikacji instrumentów finansowych, a co się z tym wiąże - także metod wyceny. W przypadku banków znaczącą pozycję stanowią też korekty odpisów z tytułu utraty wartości. Zmiany w zakresie instrumentów pochodnych zidentyfikował KGHM, szacując je na ponad $200 \mathrm{mln}$ zł. Dotyczą one zmiany sposobu ujmowania wartości czasowej opcji objętych rachunkowością zabezpieczeń. Na chwilę obecną trudno skwantyfikować zmiany w zakresie rachunkowości instrumentów pochodnych, gdyż MSSF 9 nakazuje implementację prospektywnie, z wyjątkiem ujmowania wartości czasowej opcji, co oszacował KGHM. Dlatego też empiryczna weryfikacja omówionych zmian i ich wpływu na wierny i rzetelny obraz instrumentów pochodnych w sprawozdaniach finansowych będzie możliwa dopiero w przyszłości. Niemniej jednak cie- 
kawym obszarem badań wydaje się wpływ MSSF 9 na obraz pierwotnych instrumentów finansowych (papierów wartościowych, kredytów, pożyczek), zwłaszcza w sprawozdaniach finansowych banków.

\section{Podsumowanie}

MSR 39 stwarzał jednostkom gospodarczym, zwłaszcza podmiotom niefinansowym, spore problemy implementacyjne i w wielu sytuacjach nie pozwalał na wierną prezentację instrumentów pochodnych, to znaczy zgodną z ich treścią ekonomiczną. Dlatego też zmiany w rachunkowości instrumentów pochodnych były konieczne. Czas, jaki Rada Międzynarodowych Standardów Rachunkowości poświęciła na opracowanie nowego standardu (pierwszy projekt opublikowano w 2009 roku), pozwalał przypuszczać, że w rachunkowości instrumentów pochodnych zostaną wprowadzone gruntowne zmiany poprawiające niedoskonałości MSR 39. Niestety, w przypadku instrumentów pochodnych wiele problemów nie zostało w ogóle rozwiązanych. Jednostki gospodarcze w dalszym ciągu mogą dobrowolnie stosować model rachunkowości zabezpieczeń, co w praktyce oznacza, że instrumenty zabezpieczające mogą być ujmowane i prezentowane w taki sam sposób jak instrumenty spekulacyjne. Mając na uwadze ich całkowicie odmienny cel i charakter, nasuwa się pytanie o jakość sprawozdań finansowych i ich wiarygodność.

Część wprowadzonych zmian jest dyskusyjna z punktu widzenia ich wpływu na wierny i rzetelny obraz jednostki gospodarczej. Dotyczy to głównie zmian w zakresie pomiaru efektywności, a w szczególności odejścia od jednoznacznie zdefiniowanej miary wysokiej efektywności oraz możliwości zmiany metody jej mierzenia $w$ trakcie trwania zabezpieczenia. Jednostki mogą ulec pokusie, aby dążyć jedynie do zaprezentowania wysokiej skuteczności zabezpieczenia, a nie do osiągnięcia rzeczywistej skuteczności, co może doprowadzić do pogorszenia wiarygodności sprawozdań finansowych jednostek gospodarczych (Andrzejewski, Dunal, 2016). W konsekwencji porównywalność informacji między spółkami i okresami zostanie zaburzona. Ponadto swoboda w zakresie pomiaru i definiowania skuteczności stwarza możliwości manipulacji i kreowania wyników finansowych oraz może powodować ujmowanie w rachunkowości zabezpieczeń instrumentów niedopasowanych i o niskiej rzeczywistej efektywności (Beisland, Frestad, 2013). W konsekwencji zasada true and fair view zostaje w znacznym stopniu osłabiona.

Należy jednak podkreślić, że część zmian wprowadzonych przez MSSF 9 eliminuje niedoskonałości MSR 39 i powinna przyczynić się do poprawy jakości przekazywanych w sprawozdaniu finansowym informacji o instrumentach pochodnych. Przede wszystkim pozytywnie należy ocenić rozszerzenie katalogu 
pozycji kwalifikujących się do zabezpieczenia, wyznaczenie do powiązania komponentu ryzyka, dostosowanie zabezpieczenia w trakcie jego trwania (rebalancing) oraz brak możliwości unieważnienia stosowania rachunkowości zabezpieczeń. Te zmiany pozwalają lepiej odzwierciedlić ekonomiczny sens i efekt działań zabezpieczających.

Podsumowując, zmiany wprowadzone przez MSSF $9 \mathrm{w}$ zakresie rachunkowości instrumentów pochodnych nie poprawiają w sposób jednoznaczny wiarygodności informacji zawartej w sprawozdaniach finansowych. Wydaje się, że nacisk został położony nie na uproszczenie wymagań stosowania rachunkowości zabezpieczeń, a jedynie w pewnym zakresie na lepsze odzwierciedlenie ekonomicznych skutków stosowania instrumentów pochodnych. Pozostaje mieć nadzieję, że praktyka zweryfikuje zasady nowego standardu i wymusi kolejne zmiany. Analiza zawarta w niniejszym artykule może okazać się pomocna polskiemu ustawodawcy. Rozporządzenie Ministra Finansów z dnia 12 grudnia 2001 r. w sprawie szczegółowych zasad uznawania, metod wyceny, zakresu ujawniania i sposobu prezentacji instrumentów finansowych było ostatnio nowelizowane w 2015 roku i w dalszym ciągu zawiera rozwiązania zaczerpnięte z MSR 39. Potencjalna nowelizacja rozporządzenia implementująca rozwiązania zawarte MSSF 9 lub Krajowy Standard Rachunkowości dotyczący instrumentów finansowych mogłyby wprowadzić do polskiego prawa bilansowego część rozwiązań MSSF 9 (dotyczących wyznaczania pozycji zabezpieczanych i koncepcji rebalancing), jednocześnie zostawiając część z MSR 39 (pomiar efektywności i ilościową definicję wysokiej skuteczności). Dzięki temu zasada wiernego i rzetelnego obrazu instrumentów pochodnych w sprawozdaniach finansowych polskich spółek byłaby w większym stopniu respektowana.

\section{Bibliografia}

Andrzejewski M., Dunal P. (2016), The balance sheet under Polish regulations vs. IFRS, Anglo-American University, Praga.

Andrzejewski M., Grabiński K. (2016), Wptyw jakości systemu nadzoru właścicielskiego na sytuację finansowa spółek giełdowych w czasach kryzysu finansowego - przeglad badań empirycznych, „Studia Ekonomiczne. Zeszyty Naukowe Uniwersytetu Ekonomicznego w Katowicach", nr 268, s. 9-19.

Barczyk K. (2015), Rachunkowość zabezpieczeń grupy kapitałowej. Studium przypadku, „Studia Ekonomiczne. Zeszyty Naukowe Uniwersytetu Ekonomicznego w Katowicach”, nr 225, s. $56-58$.

Beisland L.A., Frestad D. (2013), How fair-value accounting can influence firm hedging, „Review of Derivatives Research", t. 16(2), s. 193-217.

Bera A.K., Garcia P., Roj J.S. (1973), Estimation of Time-Varying Hedging Ratios for Corn and Soybeans: BGARCH and Random Coefficient Approaches, Sanklaya Series B, 59.

Bernhardt T., Erlinger D., Unterreiner L. (2014), IFRS 9: the new rules for hedge accounting from the risk management perspective, „ACRN Journal of Finance and Risk Perspectives”, t. 3, nr 3, s. 53-66. 
Charnes J.M., Koch P., Berkman H. (2003), Measuring hedge effectiveness for FAS 133 complian$c e$, ,Journal of Applied Corporate Finance”, t. 15, nr 4, s. 8-16.

Comiskey E.E., Mulford C. W. (2008), The non-designation of derivatives as hedges for accounting purposes, „The Journal of Applied Research in Accounting and Finance”, t. 3, nr 2, s. 3-16.

Conceptual Framework for Financial Reporting (2018), IASB, March.

Corman L. (2006), Lost in the maze, CFO, 22, s. 66-70.

DeMarzo P. M., Duffie D., (1995) Corporate incentives for hedging and hedge accounting, "The Review of Financial Studies", t. 8, nr 3, s. 743-771.

Dunal P., Kozik M. (2017), Problematyka pomiaru efektywności zabezpieczenia przed ryzykiem rynkowym $w$ rachunkowości instrumentów pochodnych $w$ świetle wprowadzenia MSSF 9, „Ekonomiczne Problemy Usług” nr 2(127), s. 110-120.

Fabozzi J.F., Markowitz H. (2011), The theory and practice of instrument management, John Wiley \& Sons, Hoboken.

Finnerty J.D., Grant D. (2003), Testing Hedge Effectiveness Under SFAS 113, „The CPA Journal”, April, s. 11-17.

Frendzel M. (2010), Rachunkowość instrumentów finansowych w świetle regulacji krajowych i międzynarodowych, Stowarzyszenie Księgowych w Polsce, Warszawa.

Garstecki D. (2012), Metody pomiaru efektywności zabezpieczenia w rachunkowości, [w:] H. Buk, A. Kostur, Za i przeciw wartości godziwej w rachunkowości. Problemy stosowania i wykorzystania wartości godziwej, Uniwersytet Ekonomiczny w Katowicach, Katowice.

Helin A., Drabikowska K., Sztuczyńska H. (2005), Rachunkowość instrumentów finansowych, ODiDK, Gdańsk.

Howard C.T., D'Antonio L.J. (1987), A risk-return measure of hedging effectiveness: a reply, „Journal of Finance and Quantitative Analysis", t. 22, nr 3, s. 21-27.

Ignatowski R. (2017), Rzetelny i jasny obraz w sprawozdaniach finansowych - badanie sondażowe w eksperymencie badawczym, ,Zeszyty Teoretyczne Rachunkowości”, t. 92(148), s. 47-70.

Kamela-Sowińska A., Garstecki D. (2014), Rachunkowość instrumentów finansowych, Uniwersytet Ekonomiczny w Poznaniu, Poznań.

Mazurowska M. (2015), Rachunkowość zabezpieczeń a proces zarzadzania ryzykiem w przedsiębiorstwie, ,Zeszyty Naukowe Uniwersytetu Szczecińskiego” nr 873, „Finanse, Rynki Finansowe, Ubezpieczenia" nr 77, s. 385-392.

Michelson S.E., Jordan-Wagner J., Wootton C.W. (2000), The relationship between the smoothing of reported income and risk-adjusted returns, „Journal of Economics and Finance”, t. 24, nr 2., s. 52-61.

Międzynarodowy Standard Rachunkowości 39, Rozporządzenie Komisji (UE) Nr 1126/2008 z dnia 3 listopada 2008 r. przyjmujące określone międzynarodowe standardy rachunkowości zgodnie z rozporządzeniem (WE) nr 1606/2002 Parlamentu Europejskiego i Rady (Dziennik Urzędowy Unii Europejskiej I. 320/1).

Międzynarodowy Standard Sprawozdawczości Finansowej 9, Rozporządzenie Komisji (UE) 2016/2067 z dnia 22 listopada 2016 r. zmieniające rozporządzenie (WE) nr 1126/2008 przyjmujące określone międzynarodowe standardy rachunkowości zgodnie z rozporządzeniem (WE) nr 1606/2002 Parlamentu Europejskiego i Rady w odniesieniu do Międzynarodowego Standardu Sprawozdawczości Finansowej 9 (Dziennik Urzędowy Unii Europejskiej I. 323/1).

Ożga P. (2016), Rachunkowość instrumentów pochodnych, Wydawnictwo C.H. Beck, Warszawa.

Ramirez J. (2007), Accounting for Derivatives: Advanced Hedging under IFRS, John Wiley \& Sons, Chicester.

Rashty J., O'Shaughnessy J. (2012), Foreign currency forward contracts and cash flow hedging, „The CPA Journal”, t. 82, nr 3, s. 22-27.

Ring D.M. (19997), Risk-shifting within a multinational corporation: the incoherence of the U.S. tax regime, „Boston Collage Law Review”, t. 38, nr 4, s. 75-79. 
Ryan S.G., Herz R.H., Iannaconni T.E., Maines L.A., Palepu K.G., Schrand C.M., Skinner D.J., Vincent L. (2002), Recommendations on hedge accounting and accounting for transfers of $f$ nancial instruments, „Accounting Horizons”, t. 16, nr 1, s. 81-93.

Ustawa z dnia 29 września 1994 r. o rachunkowości (Dz.U. z 2018 r., poz. 395).

Żebruń A. (2010), Instrumenty pochodne zabezpieczajace w rachunkowości, Wydawnictwo Difin, Warszawa.

\section{True and Fair View of Derivative Instruments in Hedge Accounting Model Under IFRS 9}

Abstract: Accounting of derivative instruments under International Accounting Standard 39 (IAS 39) were criticised due to the complexity and mismatch to business reality. Superseding IAS 39 with International Financial Reporting Standard 9 (IFRS 9) was aimed to simplify hedge accounting principles and contribute to the wider use of this model, and, on the other hand, to eliminate the imperfections of the previous standard and improve the quality of information on derivative instruments disclosed in the financial statements. IFRS 9 introduced a number of changes in the accounting of derivative instruments and therefore it seems reasonable to discuss their consequences and the impact on the reliability and credibility of information disclosed on derivatives. This is extremely important because derivatives are associated with a significant risk and often their improper use led to significant financial problems or even bankruptcy of enterprises and financial institutions. The purpose of this article is to present the most important changes in accounting for derivatives implemented in IFRS 9 and to analyze their impact on financial statements, i.e. true and fair reflection of economic effects of using derivatives.

Keywords: derivatives, hedge accounting, IFRS 9, IAS 39, hedge effectiveness

JEL: M41, G39

\begin{tabular}{|l|l|}
\hline OPEN ACCESS & $\begin{array}{l}\text { C by the author, licensee Łódź University - Łódź University Press, Łódź, Poland. } \\
\text { This article is an open access article distributed under the terms and conditions } \\
\text { of the Creative Commons Attribution license CC-BY } \\
\text { (http://creativecommons.org/licenses/by/3.0/) }\end{array}$ \\
\cline { 2 - 2 } \\
Received: 2018-05-05; verified: 2018-08-27. Accepted: 2018-12-20
\end{tabular}

